\title{
Evidence of the Validity of the Internal Structure of the Ethical, Transformational and Moral Leadership Scale in an Educational Portuguese Context ${ }^{1}$
}

\author{
Lurdes Gomes Neves², Joaquim Luís Coimbra ${ }^{2}$ \\ ${ }^{2}$ Universidade do Porto, Porto, Portugal
}

\begin{abstract}
In the educational context, three models of leadership with increasing importance - ethics, transformational and moral have emerged, being the most developed the model of transformational leadership. This study aimed to analyze the internal structure of leadership questionnaires in the educational context and to know the construct validity of the ethical, moral and transformational dimensions of leadership in the Portuguese educational context. In a sample of 204 teachers, it was possible to verify the behavior of the three questionnaires in the validity of the construct and in the reliability. Leadership scales (Ethical Leadership Questionnaire, Transformational Leadership Questionnaire and Moral Leadership Questionnaire) presented good levels of adjustment to the factor structure and reliability values between acceptable and excellent. Considering the results obtained of innovative character in the level of the psychometric study of the different measures in the educational context will be relevant, in the future, to assess their concurrent validity in different samples of teachers.
\end{abstract}

Keywords: leadership, psychological evaluation, measures, teachers

\section{Evidências de Validade da Estrutura Interna da Escala de Liderança Ética, Transformacional e Moral no Contexto Educativo Português}

\begin{abstract}
Resumo: No contexto educativo têm emergido três modelos de liderança com crescente importância - ética, transformacional e moral - sendo o mais desenvolvido o modelo de liderança transformacional. Este estudo teve como objetivo analisar a estrutura interna dos questionários de liderança em contexto educativo e conhecer a validade de constructo das dimensões ética, moral e transformacional da liderança no contexto educativo português. Numa amostra de 204 professores foi possível verificar o comportamento dos três questionários na validade de constructo e na fiabilidade. As escalas de liderança (Questionário de Liderança Ética, Questionário de Liderança Transformacional e Questionário de Liderança Moral) apresentaram bons níveis de ajustamento à estrutura fatorial e valores de fiabilidade entre aceitável e excelente. Tendo em conta os resultados obtidos de carácter inovador em nível do estudo psicométrico das diferentes medidas no contexto educativo será relevante, futuramente, aferir a sua validade concorrente em diferentes amostras de professores.
\end{abstract}

Palavras-chave: liderança, avaliação psicológica, medidas, professores

\section{Evidencias de Validez de la Estructura Interna de la Escala de Liderazgo Ética, Transformacional y Moral en el Contexto Educativo Portugués}

\begin{abstract}
Resumen: En el contexto educativo han surgido tres modelos de liderazgo con creciente importancia - ética, transformacional y moral -, siendo el más desarrollado el modelo de liderazgo transformacional. Este estudio tuvo como objetivo analizar la estructura interna de los cuestionarios de liderazgo en un contexto educativo y conocer la validez de constructo del liderazgo ético, moral y de transformación en el contexto educativo portugués. En una muestra de 204 profesores fue posible verificar el comportamiento de los tres cuestionarios en la validez de constructo y en la fiabilidad. Las escalas de liderazgo (Cuestionario de Liderazgo Ético, Cuestionario de Liderazgo Transformacional y Cuestionario de Liderazgo Moral) presentaron buenos niveles de ajuste a la estructura factorial y valores de fiabilidad entre aceptable y excelente. Teniendo en cuenta los resultados obtenidos de carácter innovador a nivel del estudio psicométrico de las diferentes medidas en el contexto educativo, será pertinente, en el futuro, medir su validez competitiva en diferentes muestras de profesores.
\end{abstract}

Palabras clave: liderazgo, evaluación psicológica, medidas, profesores

${ }^{1}$ Paper deriving from the doctoral dissertation by the first author, under the advice of the second author and co-advice of the second author, under the Doctoral Program in Psychology at Universidad do Porto, Portugal.

Correspondence address: Lurdes Gomes Neves. Universidade do Porto. Departamento de Psicologia. Rua Alfredo Allen. Porto, Portugal. 4200-135.

E-mail: mluneves@gmail.com
Over the last decade, the literature on leadership in educational institutions has proliferated all over the world (Ferreira \& Flores, 2012; Flores, 2014; Frost, 2012), being considered one of the key variables for the development of 
teachers and of schools. Although the set of definitions is vast, there is some confluence in the representation of leadership as a process of influence exerted to reach certain objectives (Castanheira et al., 2007). In this context, the leader (for example, the school director) plays a particularly important role in that he or she can articulate, encourage and mobilize his or her followers - teachers, specialized technicians and assistants of educational action - to achieve the objectives with the construction of a quality education, the improvement of the skills acquired and the results obtained by the students.

Regarding the historical evolution of the issue of leadership in an educational context, several works such as Bass (2008), Bush (2011) or Yukl, Mahsud, Hassan and Prussia (2011) stand out. It should be noted that there are studies carried out on this subject in different countries, from Australia (Blackmore, 2004), to the comparative study between Portugal and England (Day, Flores, \& Viana, 2007) and, in Portugal, the meta-analysis on educational leadership (Costa, Figueiredo, \& Castanheira, 2013). The systematic review of the literature is also highlighted in Portugal (Castanheira \& Costa, 2011) and in the United States (Jacobs, Gordon, \& Solis, 2016; Lieberman \& Miller, 2004), in the United Kingdom (Frost, 2012; Frost \& Durrant, 2003; Muijs $\&$ Harris, 2006) and in Brazil (Polon, 2011).

From the many theories of leadership produced, there have emerged three with increasing importance - ethics, transformational and moral (Ferreira \& Flores, 2012), making it particularly relevant to analyze how these constructs are evaluated in an educational context. structure of leadership questionnaires in educational context and to know the construct validity of the ethical, moral and transformational dimensions of leadership in the Portuguese educational context). In this way, it will be possible to know the construct validity of the ethical, moral and transformational dimensions of leadership in the context of this sample of the Portuguese educational context.

\section{Ethical Leadership}

When the institutional mission is limited to the education, training and development of children and young people, the exercise of leadership, not only transformational but also ethical and moral, takes on a more significant relevance, with evident effects on society in general. The ethical and moral dimension of organizational activity has become, for more than a decade up to now, one of the main concerns of managers, politicians and researchers, due to its consequences in relations and in all organizational activity (Brown \& Treviño, 2006; Brown, Treviño, \& Harrison, 2005; Robertson, Crittenden, Brady, \& Hoffman, 2002; Yukl et al., 2011), particularly when these relate to the educational context, taking into account the responsibility of these institutions in society. Consequently, the effects of the ethical and moral conduct of the institutions and their leaders, representatives in interpersonal relations with teachers, are determinant for the health and psychosocial well-being of all those involved in the educational process. On the other hand, the concept of ethical leadership refers to the behaviors of the leader, which meet the organization's moral beliefs and values, particularly in ethical organizations that guide their mission in accordance with current moral standards and act in a socially responsible way (Brown et al., 2005).

Other leadership models have been introduced and narrow the focus on ethical issues, which have been specifically developed to understand the effects of ethical leaders on their followers, as in the case of Brown et al. (2005) in which ethical leadership was considered as the "normatively appropriate demonstration to be carried out through personal actions and interpersonal relationships and the promotion of such conduct to followers through two-way communication, reinforcement and decision-making" (Brown et al., 2005, p. 120).

Following this, De Hoogh and Den Hartog (2008) constructed an instrument, adapted from the Multicultural Leadership Behavior Questionnaire (Hanges \& Dickinson, 2004), which allows the evaluation of ethical leadership (Ethical Leadership Scale). For the authors, although there is a continuum between ethical and despotic leadership, these are treated as independent and negatively correlated constructs, which we will attempt to validate in the present study in an educational context.

\section{Transformational Leadership}

When the concept of transformational leadership was first introduced, Burns (1978), invoking Kohlberg's (1969) cognitive theory of moral development, argued that transformational leaders could lead their followers to progress in stages of moral reasoning. Howell and Avolio (1992) also demonstrated that transformational leaders can act both ethically and unethically, depending on the moral values they incorporate into their strategy and program vision, which becomes particularly relevant in the educational context. Later, the morality referred to in transformational leadership was seriously questioned because each of the four components of transformational leadership construction - idealized influence, inspired motivation, intellectual stimulation, and individualized consideration - has an ethical dimension, but as Ardichvili (2001) acknowledged, is morally neutral.

Castanheira and Costa (2011) conducted a meta-analysis focused on the Portuguese reality in the educational context, based on the use of the Multifactor Leadership Questionnaire (Bass \& Avolio, 2003), indicating the predominance of the type of transformational leadership and transactional leadership in Portuguese public schools. In this meta-analysis, individual consideration and inspirational motivation stood out as the most observed factors in transformational leadership. In the transactional leadership, contingent reward seems to be the underlying factor of the most observed behaviors.

Bass (1990) expanded this concept by formulating a model in which transformational leadership involves the leaders' active influence on the motivation of followers at the level of their attitudes, inspiring them to achieve the goals. This model presupposes the existence of four main components: charismatic, which induces admiration, respect and trust in their followers; motivational, which enables followers to achieve higher objectives and goals; intellectual stimulation, that challenges followers to move out of their comfort zone and encourages 
them to develop their skills more creatively; individualized consideration, that is, respect for the individuality and identity of each follower. Transformational leadership thus comprises the achievement of the leader concomitant with the sense of collective efficacy and competence, since followers seem to obtain greater satisfaction, involvement and commitment to the goals and objectives of the educational organization (Castanheira \& Costa, 2011).

\section{Moral Leadership}

Moral intelligence applied to leadership has been defined as the ability to distinguish right from wrong, to possess strong moral convictions, and to behave appropriately to the leader's context of action. Thus, moral intelligence refers to how universal principles are applied to our values, objectives and performance (Lennick \& Kiel, 2011). It is worth mentioning the distinction between moral intelligence and emotional intelligence, since the latter is devoid of values and can be applied "both for good and for evil," while moral intelligence is, by definition, "directed toward well "(Lennick \& Kiel, 2011). This concept gains particular relevance in the educational context, since the integrity of the leader seems to be an important predictor of the behavior, motivation, satisfaction and investment of the followers (Canrinus, Helms-Lorenz, Beijaard, Buitink, \& Hofman, 2012; Mamede, Ribeiro, Gomes, \& Rego, 2014).

Lennick and Kiel (2011) Lennick and Kiel (2011) argue that morally more competent leaders reveal greater consistency in their behaviors and greater alignment with moral principles, values and beliefs, which result in positive consequences for the organization. For these authors Moral Intelligence involves four dimensions: integrity, that is, acting in a manner consistent with universal principles, values and personal beliefs, telling the truth and upholding what is right and keeping the promises; responsibility, for his or her personal choices, admitting his or her mistakes and failures, and taking responsibility for his or her followers; compassion, that is, caring for others; forgiveness, that is, forgive his or her own mistakes and failures and so on as others. These dimensions are evaluated in the questionnaire that the authors constructed - the Moral Competency Inventory, which was the basis of the elaboration of the instrument used in the present study as the Moral Leadership Scale of Mamede, Ribeiro and Gomes (2010), which is validated for the Portuguese population.

Considering the constructs under study, the present research aimed to analyze the internal structure of leadership questionnaires in the educational context and to know the construct validity of the ethical, moral and transformational dimensions of leadership in the Portuguese educational context. By means of statistical analysis focused on the construct validity and the reliability of the items by means of exploratory and confirmatory factor analysis, we intend to test the factor validity of the measure (Field, 2013; Osborne \& Fitzpatrick, 2012) in an educational context.

\section{Method}

\section{Participants}

The sample consisted of 204 teachers from 30 school groups (that is, a group of schools that constitute organizational units of the Portuguese educational system, with their own administrative and management bodies), from the North and Center of Portugal, with school levels from the pre-school to secondary education, of which 156 $(76.5 \%)$ are female. Regarding the age, 26 participants $(12.7 \%)$ present ages up to 40 years, $87(42.6 \%)$ are between 40 and 50 years and $91(44.6 \%)$ are between 50 and 60 years. The majority, $98(48.0 \%)$ have more than 25 years of professional experience.

\section{Instruments}

Teachers answered a sociodemographic questionnaire, fundamental for a better understanding of the study population, and information was collected on the age, sex and length of service of the directors, and on validated leadership questionnaires to the Portuguese population. The Ethical Leadership Questionnaire - ELQ (Neves, Jordão, Cunha, Vieira, \& Coimbra, 2016) with the reliability index of $\alpha$ of .96 on the ethical subscale and .91 on the subscale "Despotic"), the Transformational Leadership Questionnaire - TLQ (Bass \& Avolio, 2003), with the index of $\alpha=.92$ in the Transformational subscale, $\alpha=.87$ in the Transactional subscale and $\alpha=.70$ in the Laissez-Faire subscale) and the Moral Leadership Questionnaire - MLQ (Mamede et al., 2010) with the reliability index of $\alpha=.84$ in the Integrity scale, the $\alpha=.73$ in the Forgiveness subscale, with the $\alpha=.93$ in the subscale "Responsibility" and $\alpha=.61$ in the subscale "Compassion"“).

The Ethical Leadership Questionnaire (ELQ) by Neves et al. (2016) consists of 23 items, graded on a Likert scale of 1 to 7 points $(1=$ strongly disagree, $7=$ strongly agree $)$ and assesses ethical leadership in two dimensions: "Ethical Leadership" and "Despotism." Ethical leadership considers how leaders should behave in the face of how they behave in practice. Despotic leadership reflects authoritarian behavior that serves the selfinterest of the leader and translates into self-centeredness, insensitivity, and exploitation of others. Both subscales have good reliability ( $\alpha=.96$ and .91 respectively).

The Transformational Leadership Questionnaire (TLQ) by Bass and Avolio (2003) consists of 45 items, rated on a Likert scale of 0 to 4 points $(0=$ never, $4=$ frequently $)$. It aims to measure the frequency with which transformational leadership behaviors (the leader promotes motivation and change of attitudes of followers to inspire them to achieve the goals), transactional (the leader resorts to a system of rewards and punishments based on whether or not the goals are met), "laissez-faire" (the leader does not show leadership behaviors and abdicates taking decisions and taking responsibility) and leadership results (effectiveness, satisfaction and extra effort) are observed by the followers. In this study, only the 36 items related to leadership behaviors were used. All the used subscales 
presented acceptable reliability ( $\alpha=.92$ Transformational, $\alpha=$ .87 Transactional, and $\alpha=.70$ Laissez-Faire).

The Moral Leadership Questionnaire (MLQ) by Mamede et al. (2010) is made up of 12 items, graded on a Likert scale of 1 to $5(1=$ never, $5=$ all situations $)$. It seeks to assess the leader's moral and emotional competence through four dimensions: "Integrity," "Responsibility," "Compassion," and "Forgiveness." Although the Compassion subscale presented mediocre reliability $(\alpha=.61$, but still acceptable for emergent measures), the subscales generally show good reliability $(\alpha=.84$ "Integrity", $\alpha=.93$ "Responsibility", and $\alpha=.73$ "Forgiveness").

\section{Procedure}

Data collection. Initially, a face-to-face contact was made with the directors of 30 secondary schools and school groups, which explained the objectives of the present study and asked to participate in this study by sending the sociodemographic questionnaire and the validated leadership questionnaires for the Portuguese population: the Ethical Leadership Questionnaire, the Transformational Leadership Questionnaire and the Moral Leadership Questionnaire for all teachers. In addition, the questionnaires were placed by the director, in the online portal of each school and grouping, for the completion by the teachers and the contact was made by mail with them, requesting completion, reinforcing the request in the opening meetings of the school year to all teachers in each grouping. They were also asked to forward the mail to their fellow teachers under the same conditions. The collection took place between August and October 2015 and 204 valid questionnaires were collected.

Data analysis. he collected data were inserted in a base to analyze: (I) the underlying factor structure and the homogeneity of the items within each of the scales, through the use of exploratory factor analysis (main axis factorization); (II) to verify reliability through the internal consistency indicator (Cronbach's alpha); (III) and to verify the psychometric quality of the evaluation model through the confirmatory factor analysis (maximum likelihood method).

Next, reliability was verified by calculating the Cronbach alpha coefficient $(\alpha)$ as presented in Table 1 and composite reliability (CR) taking the threshold of .70 as an indicator of sufficient reliability. The convergent validity was verified through Average Variance Extracted (AVE) in conjunction with $\mathrm{CR}$. The discriminant validity was analyzed by comparing AVE with the Maximum Shared Squared Variance (MSV) and the Average Shared Squared Variance (ASV). For the calculation of CR, AVE, MSV and ASV the guidelines of Hair, Hult, Ringle and Sarstedt (2013) were followed.

The same source was used for the RMSEA reference values (Rigdon, 1996, TLI (Tucker \& Lewis, 1973) and the CFI Comparative Fit Index by Chen (2007). Finally, the Statistical Package for the Social Sciences ${ }^{\circledR}$ (SPSS, version 22.0) and the Analysis of Moment Structures ${ }^{\circledR}$ (SPSS AMOS, version 19.0) were used for the realization of the statistical databases and analyses.

\section{Ethical Considerations}

The principle of participation in this study was based on the Ethics Committee about the methodology of the research project of the Faculdade de Psicologia e de Ciências da Educação from Universidade do Porto and an informed, free and express decision about the nature, implications and risks of this participation, and the information for informed, free and express consent was provided to the participants. This information was provided before they had access to the questionnaire and also at the beginning of the questionnaire itself.

\section{Results}

Initially, the factor validity of the scales was checked by AFC and, in the analyses performed, all items with lambdas $<$ .50 , and that did not present important theoretical implications for the model in question, were withdrawn, following the recommendations of Hair et al. (2013). The criteria adopted to verify the level of adjustment of the model were those suggested by Brown (2015) and $\mathrm{Hu}$ and Bentler (1999). To simplify the interpretation of the results, only the adjustment indexes considered fundamental by $\mathrm{Hu}$ and Bentler (1999) will be exposed.

Then reliability was verified by calculating the Cronbach alpha coefficient (a) as presented in Table 1 and Composite Reliability (CR) taking the threshold of .70 as an indicator of sufficient reliability. Convergent validity was verified through Average Variance Extracted (AVE) in conjunction with CR. The discriminant validity was analyzed by comparing AVE with Maximum Shared Squared Variance (MSV) and Average Shared Square Variance (ASV). For the calculation of CR, AVE, MSV and ASV, the guidelines of Hair et al. (2013).

Table 1

Reliability values (Cronbach's alpha)

\begin{tabular}{lccc}
\hline & \multicolumn{3}{c}{ Studies } \\
\cline { 2 - 4 } & Adaptation & \multicolumn{2}{c}{ Present } \\
\cline { 2 - 4 } ELQ & $\mathrm{A}$ & $\alpha$ & Average (S.D.) \\
Ethical & & & \\
Despotic & .95 & .96 & $5.46(1.06)$ \\
\hline TLQ ${ }^{1}$ & .89 & .91 & $2.44(1.28)$ \\
Transformational & & & \\
Transactional & & .92 & $2.48(.73)$ \\
Laissez-Faire & & .87 & $2.14(.63)$ \\
\hline MLQ & & .70 & $1.10(.72)$ \\
Integrity & & & \\
Forgiveness & .70 & .84 & $4.04(.66)$ \\
Responsibility & .70 & .73 & $3.57(.57)$ \\
Compassion & .70 & .93 & $3.83(.82)$ \\
\hline
\end{tabular}

Note. 1 . No validation studies were found that found this structure. 2 . The authors only present an approximate value for all dimensions. 
Finally, correlational analyses were performed between all scales under study. In Table 1 it is possible to observe the Cronbach's alpha values found in this study contrasted with the adaptation studies of the original Portuguese versions.

\section{Ethical Leadership}

The model tested showed very good adjustment levels in all measures analyzed (Table 2). From the tested model, two items with lambda values $<.50$ were removed. Analyzing Table 2, it was possible to verify that, at the reliability level, both dimensions presented values of $\mathrm{CR}>.70$ and with respect to the convergent validity, it was possible to verify that the $\mathrm{CR}>\mathrm{AVE}$ and that the value of the AVE $>.500$ in all dimensions. Regarding the discriminant validity, it was observed that the values of MSV and ASV are lower than the values of the AVE.

Table 2

Ethical Leadership: indexes of adjustment, reliability, convergent and discriminant validity

\begin{tabular}{|c|c|c|c|c|c|c|c|}
\hline Dimensions & Items & $\lambda$ & $\mathrm{CR}$ & AVE & MSV & ASV & Fit Indexes \\
\hline \multirow{15}{*}{ Ethical } & Et_1 & .79 & \multirow{15}{*}{.96} & \multirow{15}{*}{.60} & \multirow{15}{*}{.53} & \multirow{15}{*}{.53} & \\
\hline & Et_2 & .77 & & & & & \\
\hline & Et_3 & .82 & & & & & \\
\hline & Et_4 & .69 & & & & & \\
\hline & Et_5 & .71 & & & & & \\
\hline & Et_6 & .79 & & & & & \\
\hline & Et_7 & .84 & & & & & \\
\hline & Et_8 & .72 & & & & & RMSEA $=.040$ \\
\hline & Et_9 & .76 & & & & & $\operatorname{RMSEA}(90 \% \mathrm{CI})=.031-.049$ \\
\hline & Et_10 & .83 & & & & & PCLOSE $=.967$ \\
\hline & Et_11 & .83 & & & & & \\
\hline & Et_12 & .75 & & & & & $\mathrm{SRMR}=.032$ \\
\hline & Et_13 & .80 & & & & & $\mathrm{TLI}=.981$ \\
\hline & Et_14 & .77 & & & & & $\mathrm{CFI}=.989$ \\
\hline & Et_15 & .74 & & & & & \\
\hline \multirow{6}{*}{ Despotic } & Desp_1 & .79 & \multirow{6}{*}{.93} & \multirow{6}{*}{.68} & \multirow{6}{*}{.53} & \multirow{6}{*}{.53} & \\
\hline & Desp_2 & .87 & & & & & \\
\hline & Desp_3 & .76 & & & & & \\
\hline & Desp_4 & .66 & & & & & \\
\hline & Desp_5 & .88 & & & & & \\
\hline & Desp_6 & .96 & & & & & \\
\hline
\end{tabular}

\section{Transformational Leadership}

The model tested showed acceptable adjustment levels in all indexes analyzed (Table 3). From the tested model, 14 items with lambda values $<.50$ were removed. Analyzing Table 3 it is possible to verify that, at the level of reliability, the dimensions present values of $\mathrm{CR}<.70$. Regarding the convergent validity, it was possible to verify that $\mathrm{CR}>$ $\mathrm{AVE}$ and it was verified, however, that in the transactional dimension the value of the AVE is <.50. Regarding the discriminant validity, it was observed that both MSV and ASV values were higher than the AVE values. 
Table 3

Transformational Leadership: indexes of adjustment, reliability, convergent and discriminant validity

\begin{tabular}{|c|c|c|c|c|c|c|c|}
\hline Dimension & Items & $\lambda$ & $\mathrm{CR}$ & AVE & MSV & ASV & Fit Indexes \\
\hline \multirow{11}{*}{ Transformational } & IIA_1 & .78 & \multirow{11}{*}{.94} & \multirow{11}{*}{.57} & \multirow{11}{*}{.76} & \multirow{11}{*}{.65} & \\
\hline & IIA_2 & .73 & & & & & \\
\hline & IIA_3 & .71 & & & & & \\
\hline & IIB_3 & .74 & & & & & \\
\hline & IM_3 & .78 & & & & & \\
\hline & IM_4 & .75 & & & & & \multirow{3}{*}{ RMSEA $=.053$} \\
\hline & IS_1 & .72 & & & & & \\
\hline & IS_2 & .72 & & & & & \\
\hline & IS_3 & .78 & & & & & $\operatorname{RMSEA}(90 \% \mathrm{CI})=.040-.064$ \\
\hline & IS_4 & .83 & & & & & PCLOSE $=.349$ \\
\hline & IC_4 & .78 & & & & & \\
\hline \multirow{4}{*}{ Transactional } & MBEA_3 & .67 & \multirow{4}{*}{.78} & \multirow{4}{*}{.47} & \multirow{4}{*}{.76} & \multirow{4}{*}{.69} & $\mathrm{SRMR}=.043$ \\
\hline & CR_2 & .57 & & & & & $\mathrm{TLI}=955$ \\
\hline & CR_3 & .76 & & & & & \\
\hline & CR_4 & .73 & & & & & $\mathrm{CFI}=.965$ \\
\hline \multirow{7}{*}{ Laissez-Faire } & MBEP_1 & .71 & \multirow{7}{*}{.88} & \multirow{7}{*}{.53} & \multirow{7}{*}{.62} & \multirow{7}{*}{.59} & \\
\hline & MBEP_2 & .68 & & & & & \\
\hline & MBEP_4 & .62 & & & & & \\
\hline & $\mathrm{LF}_{-} 1$ & .72 & & & & & \\
\hline & LF_2 & .79 & & & & & \\
\hline & $\mathrm{LF}_{-} 3$ & .79 & & & & & \\
\hline & LF_4 & .75 & & & & & \\
\hline
\end{tabular}

\section{Moral Leadership}

Regarding moral leadership, the tested model presented good levels of adjustments in all verified indexes (Table 4) and did not present items with values of lambda $<.50$. Analyzing Table 4, it was possible to verify that, in terms of reliability, the dimensions presented acceptable alpha and
CR values, except for the dimension "Compassion", where low values of alpha and CR were observed. Regarding the convergent validity, it was possible to verify that $\mathrm{CR}>\mathrm{AVE}$ in all dimensions, but it was verified that in the dimensions "Forgiveness" and "Compassion" the value of the AVE <.50. Regarding the discriminant validity, it was observed that both the MSV and ASV values were higher than the AVE values.

Table 4

Moral Leadership: indexes of adjustment, reliability, convergent and discriminant validity

\begin{tabular}{|c|c|c|c|c|c|c|c|}
\hline Dimensions & Items & $\lambda$ & $\mathrm{CR}$ & AVE & MSV & ASV & Fit Indexes \\
\hline \multirow{3}{*}{ Integrity } & Int_1 & .69 & \multirow{3}{*}{.84} & \multirow{3}{*}{.65} & \multirow{3}{*}{.86} & \multirow{3}{*}{.82} & \multirow{3}{*}{ RMSEA $=.047$} \\
\hline & Int_2 & .86 & & & & & \\
\hline & Int_3 & .85 & & & & & \\
\hline \multirow{4}{*}{ Forgiveness } & Per_1 & .76 & \multirow{4}{*}{.70} & \multirow{4}{*}{.37} & \multirow{4}{*}{1.14} & \multirow{4}{*}{.97} & $\operatorname{RMSEA}(90 \% \mathrm{CI})=.018-.071$ \\
\hline & Per_2 & .61 & & & & & PCLOSE $=.546$ \\
\hline & Per_3 & .53 & & & & & \\
\hline & Per_4 & .51 & & & & & $\mathrm{SRMR}=.032$ \\
\hline \multirow{3}{*}{ Responsibility } & Resp_1 & .82 & \multirow{3}{*}{.90} & \multirow{3}{*}{.75} & \multirow{3}{*}{.90} & \multirow{3}{*}{.78} & $\mathrm{TLI}=.980$ \\
\hline & Resp_2 & .88 & & & & & \\
\hline & Resp_3 & .90 & & & & & $\mathrm{CFI}=.986$ \\
\hline \multirow{2}{*}{ Compassion } & Comp_1 & .69 & \multirow{2}{*}{.59} & \multirow{2}{*}{.42} & \multirow{2}{*}{1.14} & \multirow{2}{*}{.85} & \\
\hline & Comp_2 & .60 & & & & & \\
\hline
\end{tabular}




\section{Correlational analyses}

Observing Table 5, it was possible to verify that all the dimensions of the questionnaires correlate significantly, both positively and negatively. The only exception found was transactional leadership that does not correlate with despotic leadership.

Table 5

Values of Pearson correlations between the dimensions of the scales

\begin{tabular}{|c|c|c|c|c|c|c|c|c|c|}
\hline & 1 & 2 & 3 & 4 & 5 & 6 & 7 & 8 & 9 \\
\hline \multicolumn{10}{|l|}{ 1. Ethical } \\
\hline 2. Despotic & $-.62^{* *}$ & & & & & & & & \\
\hline 3. Transformational & $.70^{* *}$ & $-.50^{* *}$ & & & & & & & \\
\hline 4. Transactional & $.35^{* *}$ & -.13 & $.44^{* *}$ & & & & & & \\
\hline 5. Laissez-Faire & $-.60^{* *}$ & $.50^{* *}$ & $-.63^{* *}$ & $-.24^{* *}$ & & & & & \\
\hline 6. Integrity & $.61^{* *}$ & $-.45^{* *}$ & $.70^{* *}$ & $.32^{* *}$ & $-.61^{* *}$ & & & & \\
\hline 7. Forgiveness & $.61^{* *}$ & $-.50^{* *}$ & $.70^{* *}$ & $.34^{* *}$ & $-.53^{* *}$ & $.72^{* *}$ & & & \\
\hline 8. Responsibility & $.62^{* *}$ & $-.53^{* *}$ & $.71^{* *}$ & $.33^{* *}$ & $-.56^{* *}$ & $.79^{* *}$ & $.72^{* *}$ & & \\
\hline 9. Compassion & $.51^{* *}$ & $-.46^{* *}$ & $.60^{* *}$ & $.28^{* *}$ & $-.43^{* *}$ & $.62^{* *}$ & $.68^{* *}$ & $.57^{* *}$ & \\
\hline
\end{tabular}

$* * p<.01$.

\section{Discussion}

The present study aimed to analyze the internal structure and the psychometric validation of three questionnaires that evaluate ethical, transformational and moral leadership. It was possible to carry out a structural validation of the three scales in an educational context. By means of statistical analysis focused on the construct validity and the reliability of the items, through exploratory and confirmatory factor analysis, it was also possible to test the factor validity (Field, 2013; Osborne \& Fitzpatrick, 2012) of each of the three measures in educational context.

Thus, the main result of the present study evidenced a two-factor structure of the ethical leadership questionnaire. This has shown excellent reliability, similar to the profile obtained in the literature by De Hoogh and Den Hartog (2008) and follows the studies of Brown et al. (2005), Brown and Treviño (2006), Hanges and Dickinson (2004), Robertson et al. (2002) and Yukl et al. (2011).

It was verified that in the factor related to ethical leadership, the 15 items related to "Morality" and "Justice", "clarification of the role" and "sharing of power" are included. We highlight the trend of results for ethical leadership and the mean and standard deviation of the responses of 2.48 $(0.73)$ that fit into the follow-up of studies by Canrinus et al. (2012) and Mamede et al. (2014). The remaining 6 items are included in the dimension referring to "Despotic Leadership". The ethical leadership scale still showed good levels of adjustment and convergent and discriminant validity, being possible to verify that $\mathrm{CR}>\mathrm{AVE}$ and that the value of AVE $>$ .500 in all dimensions and observing that the values of MSV and ASV are lower than the AVE values. The tested model of ethical leadership showed very good levels of adjustments in all the measures analyzed and it was possible to verify that, in terms of reliability, both dimensions presented values of $\mathrm{CR}>.70$. with respect to convergent validity.

Regarding the transformational leadership scale, the CFA revealed good model adjustment results. It was verified that there are good levels of reliability and convergent validity, despite the AVE $<.05$ in the "transactional" dimension the $\mathrm{CR}>.70$, so that it can be accepted that this dimension has a good convergent validity, similar to the results obtained by Castanheira and Costa $(2011,2013)$ and following the works developed by Bass and Avolio (1993). The "transformational leadership" dimension with the mean values of the responses and standard deviation of 5.46 (1.06) was highlighted.

The tested model also reflected acceptable adjustment levels in all indexes analyzed although 14 items with lambda values $<.50$ were removed. It was also possible to verify that, in terms of reliability, the dimensions presented values of $\mathrm{CR}<.70$ and, in relation to the convergent validity, it was verified that $\mathrm{CR}>\mathrm{AVE}$. It was found, however, that in the transactional dimension the value of the AVE is $<.50$ and, with respect to the discriminant validity, it was observed that both the MSV and ASV values are higher than the AVE values.

In the present study, however, there were problems with discriminant validity across all dimensions, which may be justified by the reduced size of the sample collected. Regarding the moral leadership scale, the model tested presented good levels of adjustment to the similarity of the model defined by Lennick and Kiel (2011) and developed 
in the works of Mamede et al. (2014), as it happened in the other scales and did not present items with lambda values $<.50$. Despite this, there was a mediocre reliability in the dimension "Compassion" and problems in the convergent and discriminant validity, being these more accentuated in the dimensions "Forgiveness" and "Compassion". We highlight the high centrality and tendency of responses in the "integrity" dimension, with mean and standard deviation of the responses of 4.04 (0.66). Regarding the convergent validity, it was possible to verify that $\mathrm{CR}>\mathrm{AVE}$ in all dimensions, but it was verified that, in the dimensions "Forgiveness" and "Compassion", the AVE value <.50. Regarding the discriminant validity, it is observed that both the MSV and ASV values are higher than the AVE values. This may have been due to the small size of the sample collected or the profile of the teachers who responded.

The four-factor tested model also met the model defined by Lennick and Kiel (2011). It was possible to verify that, in terms of reliability, the dimensions presented acceptable alpha and CR values, except for the dimension "Compassion", where low values of alpha and CR were observed. The low reliability of "Compassion" can be because this dimension only includes two items, so it would be pertinent to increase the number of items in this dimension and verify its behavior. Thus, the ethical leadership scale, in comparison to the other scales used in the study was that presented, besides good indexes of adjustment, greater reliability and better convergent and discriminant validity.

The present research is a contribution to the reflection on the psychometric quality of the instruments of study of the leadership construct, particularly in educational organizations. The results show evidence of the psychometric quality of the ethical leadership scale, making possible the use of this instrument in future empirical research in the educational context. Likewise, because the scale of ethical leadership has obtained (in comparison with the other scales of transformational and moral leadership used in the study), besides good indexes of adjustment, greater reliability and better convergent and discriminant validity, it may indicate its greater relevance in the educational context.

It is still relevant to refer the tendency of the responses to the ethical dimension in the Ethical Leadership Scale, the transformational dimension in the Transformational Leadership Scale and the dimension of "integrity" in the Moral Leadership Scale. Although the present study is relevant to the understanding of the psychometric quality of evaluation instruments of the leadership construct in the educational context, it presents some potential limitations.

Firstly, the high number of items in the final instrument used may have influenced the direction of their responses. This fact may also be the basis of the differences found between this study and the literature, which mainly contemplates each scale individually, although, in the present study, it was objective to evaluate how the different instruments behaved before the same sample of respondents.

Secondly, there is also the fact that respondents are teachers, a profession considered as exhausting, so that the temporal window in which the instrument has been answered may also have influenced the results. In addition, teachers may not have understood some items, since their validation and adaptation to the educational context was also carried out in the present study, and there were no previous studies in this sense.

Thirdly, the application of the scales was restricted to a limited geographical area. Fourthly, it is still important to mention that the sample of this study is reduced and that a larger sample could provide the presentation of more robust results, namely regarding the results obtained in each of the schools and in the relationships between the constructs. It would be relevant, therefore, the replication of the present study in a sample of larger dimension. In addition to this, considering the number of answers obtained, the leadership style of each school was not considered, since in some schools the number of teachers who answered was not significant to be considered the individual characterization of each school.

Finally, given the results obtained of innovative character in the psychometric study of the different measures in the educational context, there are no references in the literature that support these results. It will therefore be relevant, in future studies, to assess the concurrent validity of the Ethical Leadership Scale by correlating it with instruments that evaluate the same concepts, as well as applying the Transformational and Moral Leadership Scales separately with different samples of teachers, in different geographic areas or countries where the Portuguese language is official, to evaluate the results obtained in terms of the psychometric quality of the instruments and above all to understand the dynamics associated with ethical leadership in the context of school administration.

\section{References}

Ardichvili, A. (2001). Leadership styles and work related values of managers and employees and manufacturing enterprises in post-communist countries. Human Resource Development Quarterly, 12(4), 363-383. doi: $10.1002 /$ hrdq. 1003

Bass, B. M. (1990). From transactional to transformational leadership: Learning to share the vision. Organizational Dynamics, 18(3), 19-31. doi:10.1016/00902616(90)90061-S

Bass, B. M. (2008). The Bass handbook of leadership: Theory, research \& managerial applications (4th ed.). New York, NY: Free Press.

Bass, B. M., \& Avolio, B. J. (2003). MLQ Multifactor Leadership Questionnaire. Redwood City, CA: Mind Garden. Retrieved from http://www.mindgarden.com/16multifactor-leadership-questionnaire

Bass, B. M., \& Avolio, B. J. (1993). Transformational leadership: A response to critiques. In M. M. Chemers \& R. Ayman (Eds.), Leadership theory and research: Perspectives and directions (pp. 49-80). San Diego, CA: Academic Press. 
Blackmore, J. (2004). Restructuring educational leadership in changing contexts: A local/global account of restructuring in Australia. Journal of Educational Change, 5(3), 267288. doi:10.1023/B:JEDU.0000041044.62626.99

Brown, T. A. (2015). Confirmatory factor analysis for applied research. New York, NY: Guilford.

Brown, M. E., Treviño, L. K., \& Harrison, D. (2005). Ethical leadership: A social learning perspective for construct development and testing. Organizational Behavior and Human Decision Processes, 97(2), 117-134. doi:10.1016/j.obhdp.2005.03.002

Brown, M., \& Treviño, L. (2006). Socialized charismatic leadership, values congruence, and deviance in work groups. Journal of Applied Psychology, 91(4), 954-962. doi: 10.1111/j.2044-8325.1990.tb00506.x

Burns, J. M. (1978). Leadership. New York, NY: Harper \& Row.

Bush, T. (2011). Theories of Educational Leadership and Management. Fourth Edition. London, England: Sage.

Castanheira, P., \& Costa, J. A. (2007). Lideranças transformacional, transacional e laissez-faire: Um estudo exploratório sobre os gestores escolares com base no MLQ [Transformational leadership, transactional and laissez-faire: An exploratory study of school administrators based on MLQ]. In C. Fino \& J. Sousa (Eds.), A escola sob suspeita [School under suspicion] (pp. 139-154). Porto, Portugal: Edições ASA.

Castanheira, P., \& Costa, J. A. (2011). In search of transformational leadership: A (meta) analysis focused on the Portuguese reality. Procedia - Social and Behavioral Sciences, 15, 2012-2015. doi:10.1016/j. sbspro.2011.04.045.

Canrinus, E. T., Helms-Lorenz, M., Beijaard, D., Buitink, J., \& Hofman, A. (2012). Self-efficacy, job satisfaction, motivation and commitment: Exploring the relationships between indicators of teachers' professional identity. European Journal of Psychology of Education, 27(1), 115-132. doi:10.1007/s10212-011-0069-2.

Chen, F. F. (2007). Sensitivity of goodness of fit indexes to lack of measurement invariance. Structural Equation Modeling: A Multidisciplinary Journal, 14(3), 464-504. doi:10.1080/10705510701301834

Castanheira, P.; Costa, J., Neto-Mendes, A., Ventura, A.,\& Rodrigues, M., . (2011). Projeto ELO - Observatório de liderança educacional: Mapeamento do quadro conceptual de análise. In C. S. Reis \& F. S. Neves (Coords.), Livro de atas do XI Congresso da Sociedade Portuguesa de Ciências da Educação (Vol. 1, pp. 313318). Guarda, Portugal: Instituto Politécnico da Guarda.
Costa, J. A; Figueiredo, S. (2013) Quadros de referência para o desempenho dos líderes escolares. Ensaio: Avaliação e Políticas Públicas em Educação [en linea] 2013, 21 (Abril-Junio) : [Fecha de consulta: 6 de agosto de 2017] Disponible en:<http://www.redalyc.org/articulo. oa? id=399538145002> ISSN 0104-4036.

Day, C., Flores, M. A., \& Viana, I. (2007). Effects of national policies on teachers' sense of professionalism: Findings from an empirical study in Portugal and in England. European Journal of Teacher Education, 30(3), 249-265. doi:10.1080/02619760701486092

De Hoogh, A. H. B., \& Den Hartog, D. N. (2008). Ethical and despotic leadership, relationships with leader's social responsibility, top management team effectiveness and subordinates' optimism: A multi-method study. The Leadership Quarterly, 19(3), 297-311. doi:10.1016/j. leaqua.2008.03.002

Ferreira, F. I., \& Flores, M. A. (2012). Repensar o sentido da comunidade de aprendizagem: Contributos para uma conceção democrática emancipatória. In M. A. Flores \& F. I. Ferreira (Orgs.), Currículo e comunidades de aprendizagem: Desafios e perspectivas (pp. 201-248). Santo Tirso, Portugal: De Facto.

Field, A. (2013). Discovering statistics using IBM SPSS statistics (4th ed.). Thousand Oaks, CA: Sage.

Flores, M. A. (2014). Profissionalismo e liderança dos professores. Santo Tirso, Portugal: De Facto.

Frost, D. (2012). From professional development to system change: Teacher leadership and innovation. Professional Development in Education, 38(2), 205-207. doi:10.1080/ 19415257.2012.657861

Frost, D., \& Durrant, J. (2003). Teacher leadership: Rationale, strategy and impact. School Leadership \& Management, 23(2), 173-186. doi:10.1080/1363243032000091940

Hair, J. F., Jr., Hult, G. T. M., Ringle, C., \& Sarstedt, M. (2013). A primer on partial least squares structural equation modeling (PLS-SEM) (2nd ed.). Thousand Oaks, CA: Sage.

Hanges, P. J., \& Dickinson, M. W. (2004). The development and validation of the GLOBE culture and leadership scales. In R. J. House, P. J. Hanges, M. Javidan, P. W. Dorfman, \& V. Gupta (Eds.), Culture, leadership, and organizations: The GLOBE study of 62 societies (pp. 122-151). Thousand Oaks, CA: Sage.

Howell, J. M., \& Avolio, B. J. (1992). The ethics of charismatic leadership: Submission or liberation? Academy Management Perspectives, 6(2), 43-54. doi:10.5465/ame.1992.4274395

Hu, L.-T., \& Bentler, P. M. (1999). Cutoff criteria for fit indexes in covariance structure analysis: Conventional criteria versus new alternatives. Structural Equation Modeling: A Multidisciplinary Journal, 6(1), 1-55. doi:10.1080/10705519909540118 
Kohlberg, L. (1969). Stage and sequence: The cognitive development approach to socialization. In D. A. Goslin (Ed.), Handbook of socialization theory and research (pp. 347-480). Chicago, IL: Rand-McNally.

Jacobs, J., Gordon, S. P., \& Solis, R. (2016). Critical issues in teacher leadership: A National Look at Teachers' Perception. Journal of School Leadership, 26(3), 374406.

Lennick, D., \& Kiel, F. (2011). Moral intelligence 2.0: Enhancing business performance and leadership success in turbulent times. Upper Saddle River, NJ: Prentice Hall.

Lieberman, A., \& Miller, L. (2004). Teacher leadership. São Francisco, CA: Jossey-Bass.

Mamede, C., Ribeiro, N., \& Gomes, D. (2010). Tradução $e$ validação do Moral Competency Inventory para avaliação do grau de inteligência moral de líderes. Livro de atas da Conferência em Investigação e Intervenção em Recursos Humanos. Retrieved from http://www.iirh10. esce.ips.pt/artigos/64.pdf

Mamede, C., Ribeiro, N., Gomes, D. R., \& Rego, A. (2014). Leader's moral intelligence and employees' affective commitment: The mediating role of transformational leadership. Jornadas Luso Espanholas de Gestão Cientifica, 14, 1-10. Retrieved from https:// www.researchgate.net/profile/Daniel_Gomes4/ publication/260198220_Leader\%27s_moral_inteligence and_employees\%27_affective_commitment the mediating_role_of_transformational_leadership/ links/02e7e5301f130dd8c4000000/Leaders-moralinteligence-and-employees-affective-commitment-themediating-role-of-transformational-leadership.pdf

Muijs, D., \& Harris, A. (2006). Teacher led school improvement: Teacher leadership in the UK. Teaching and Teacher Education, 22(8), 961-972. doi:10.1016/j. tate.2006.04.010

Neves, L., Jordão, F., Cunha, M. P., Vieira, D. A., \& Coimbra, J. L. (2016). Estudo de adaptação e validação de uma escala de perceção de liderança ética para líderes portuguese. Análise Psicológica, 34(2), 165-176. doi:10.14417/ap.1028

Osborne, J. W., \& Fitzpatrick, D. C. (2012). Replication analysis in exploratory factor analysis: What it is and why it makes your analysis better. Practical Assessment, Research \& Evaluation, 17(15), 1-8.

Polon, T. L. P. (2011, outubro). Perfis de liderança e seus reflexos na gestão escolar. Trabalho apresentado na Trigésima Quarta Reunião Anual da ANPED, Rio de Janeiro, RJ.

Rigdon, E. E. (1996). CFI versus RMSEA: A comparison of two fit indexes for structural equation modeling. Structural Equation Modeling: A Multidisciplinary Journal, 3(4), 369-379. doi:10.1080/10705519609540052
Robertson, C. J., Crittenden, W., Brady, M. K., \& Hoffman, J. J. (2002). Situational ethics across borders: A multicultural examination. Journal of Business Ethics, 38(4), 327-338. doi:10.1023/A:1016067231599

Tucker, L. R., \& Lewis, C. (1973). A reliability coefficient for maximum likelihood factor analysis. Psychometrika, 38(1), 1-10. doi:10.1007/BF02291170.

Yukl, G., Mahsud, R.,Hassan, S., \& Prussia G. E. (2013). An Improved Measure of Ethical Leadership. Journal of Leadership \& Organizational Studies, 20(1), 38-48. doi: $10.1177 / 1548051811429352$.

Lurdes Gomes Neves is an Auxiliary Invited Professor of Faculdade de Engenharia from Universidade do Porto, Porto-Portugal.

Joaquim luís Coimbra is an Associated Professor of Faculdade de Psicologia e de Ciências da Educação from Universidade do Porto, Porto-Portugal.

Authors' Contribution:

All authors made substantial contributions to the conception and design of this study, to data analysis and interpretation, and to the manuscript revision and approval of the final version. All the authors assume public responsability for content of the manuscript.

Received: Aug. 07, 2016

1st Revision: Apr. 05, 2017

Approved: Aug. 02, 2017

How to cite this article:

Neves, L., \& Coimbra, J. L. (2019). Evidence of the validity of the internal structure of the ethical, transformational and moral leadership scale in an educational Portuguese context. Paidéia (Ribeirão Preto), 29, e2904. doi: http://dx.doi.org/10.1590/1982-4327e2904 